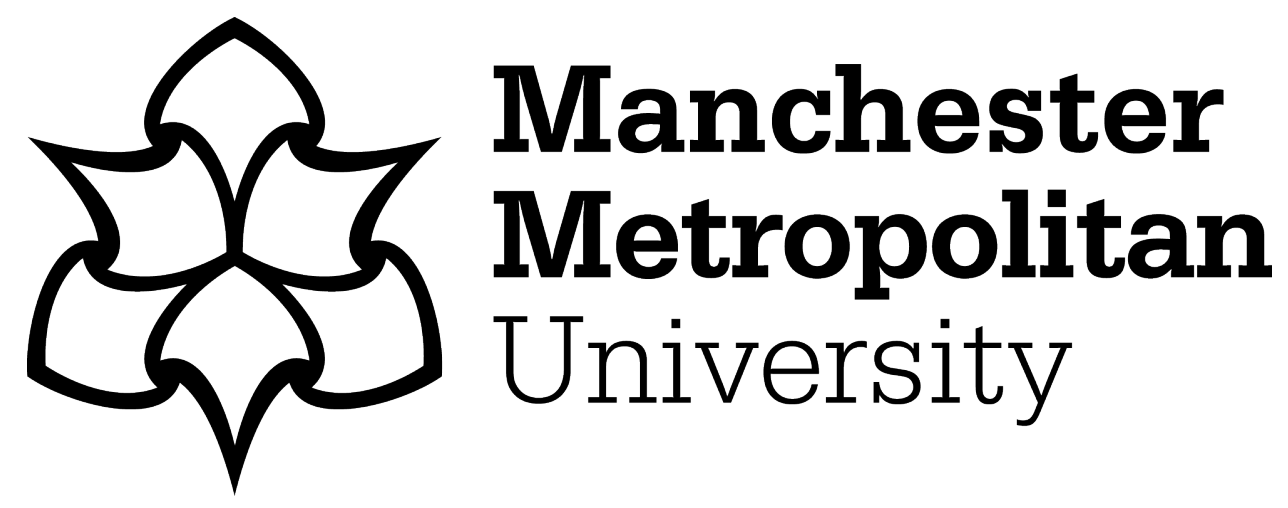

Hallett, N ORCID logoORCID: https://orcid.org/0000-0003-3115-8831 (2020) Lack of perceived competence is linked to perceived workplace bullying among Jordanian registered nurses. Evidence-Based Nursing, 23 (1). p. 30. ISSN 1367-6539

Downloaded from: https://e-space.mmu.ac.uk/623140/

Version: Accepted Version

Publisher: BMJ Publishing Group

DOI: https://doi.org/10.1136/ebnurs-2018-103009

Please cite the published version 


\section{Evidence-Based Nursing}

A lack of perceived competence is linked to perceived workplace bullying amongst Jordanian registered nurses

\begin{tabular}{|c|c|}
\hline Journal: & Evidence Based Journals \\
\hline Manuscript ID & ebnurs-2018-103009.R2 \\
\hline Manuscript Type: & Commentary \\
\hline Edition: & Default Edition \\
\hline $\begin{array}{r}\text { Date Submitted by the } \\
\text { Author: }\end{array}$ & $n / a$ \\
\hline Complete List of Authors: & $\begin{array}{l}\text { Hallett, Nutmeg; University of Birmingham, School of Nursing; } \\
\text { Manchester Metropolitan University, Nursing }\end{array}$ \\
\hline Keywords: & \\
\hline
\end{tabular}

\section{SCHOLARONE \\ Manuscripts}


Author's declarative title: A lack of perceived competence is linked to perceived workplace bullying amongst Jordanian registered nurses

Commentary on: Obeidat RF, Qan'ir Y, Turaani $\mathrm{H}$. The relationship between perceived competence and perceived workplace bullying among registered nurses: A cross sectional survey. Int J Nurs Stud 2018; 88:71-78.

\section{Commentary \\ Implications for practice and research}

- Workplace bullying is a significant issue and should be addressed at all levels.

- Future research should explore the link between workplace bullying and actual competence, and identify whether workplace bullying leads to a lack of perceived competence, or that less competent nurses attract higher levels of bullying.

\section{Context}

Bullying in nursing has received much attention over the years, from the idea that nurses 'eat their young'1 to recent UK media reports that NHS directors will have a legal duty to act on bullying ${ }^{2}$. Bullying in nursing appears to be a universal phenomenon, identified in studies across the globe at rates between $5-87 \%^{3}$. Workplace bullying may be linked with a whole range of negative experiences including reduced perceived job performance and lower job satisfaction ${ }^{4}$.

\section{Methods}

The aim of the study 5 was to identify the prevalence of workplace bullying amongst Jordanian registered nurses, differences in rates by demographic and clinical factors, and the relationship between perceived bullying and perceived competence. The study used a cross-sectional survey design incorporating a demographic data sheet, the Negative Act Questionnaire-Revised (NAQ-R) and the Nurse Professional Competence scale (NPC). A convenience sample of 274 nurses were recruited and 269 completed questionnaires were returned. Overall bullying scores, summation of 22 items from the NAQ-R, and workplace bullying category scores (person-related, work-related, physical intimidation) were calculated, with bivariate analyses run between these and demographic variables, and perceived competence as measured by the NPC. Multiple linear regression was run to identify predictors of perceived bullying.

\section{Findings}

Almost half of participants (43\%) perceived themselves to be victims of severe workplace bullying, whilst $26 \%$ perceived no bullying. Person-related bullying was the most frequently reported type, with physically intimidating bullying the least. Superiors or managers were most frequently reported as the source of bullying, followed by immediate superiors then colleagues. Men reported higher rates of bullying, as did single participants, whereas age and experience were negatively associated with bullying. Furthermore the higher the perceived competence, the lower the perceived bullying. In the multiple linear regression analysis, age, gender and perceived competence were the significant predictors of bullying, with competence explaining the most variance.

\section{Commentary}

Prevalence rates of bullying in this study are higher than in Europe and the USA but comparable with other studies in the Middle East ${ }^{3}$. Few studies identify the effect of gender on bullying in nursing, however being in a gender minority, as men usually are in nursing, may be a risk factor for bullying 6 . In Jordan, male nurses outnumber females, yet the male nurses in this study still reported higher levels of bullying than their female counterparts. The authors posit that this might be cultural, stating that Jordanians pride themselves on 
magnanimity toward women. This study does provide further evidence that nurses 'eat their young' with younger participants reporting higher levels of bullying.

There are limitations to this study, as identified by the authors. Whilst they found that there was a strong relationship between perceived competence and perceived bullying, the study design does not enable causal relationships to be inferred. Is it that less competent nurses are more likely to experience workplace bullying, or that bullying itself causes a reduction in competence? This study did not investigate actual competence, rather self-assessed competence and this introduces a further confounder. Perhaps nurses who are bullied cannot realistically assess their own skills. Furthermore, because age and experience are inversely related to bullying, is it that nurses with more experience perceive themselves to have greater competence? Findings from this study support existing evidence linking bullying and workplace factors ${ }^{4}$.

\section{References}

1. Meissner, J. Nurses: Are we eating our young? Nursing, 1986; 16:51-53.

2. Merrick, R, NHS bosses will be sacked if they fail to stamp out 'alarming' bullying of hospital staff, The Independent. 2018, 14 September.

https://www.independent.co.uk/news/uk/politics/nhs-staff-bullying-abuse-health-workersuk-government-crackdown-a8538166.html

3. Spector, PE, ZE Zhou, and XX Che. Nurse exposure to physical and nonphysical violence, bullying, and sexual harassment: A quantitative review. International Journal of Nursing Studies, 2014; 51:72-84.

4. Olsen, E, G Bjaalid, and A Mikkelsen. Work climate and the mediating role of workplace bullying related to job performance, job satisfaction, and work ability: A study among hospital nurses. Journal of Advanced Nursing, 2017; 73:2709-2719.

5. Obeidat, RF, Y Qan'ir, and H Turaani. The relationship between perceived competence and perceived workplace bullying among registered nurses: A cross sectional survey. International Journal of Nursing Studies, 2018; 88:71-78.

6. Salin, $\mathrm{D}$ and $\mathrm{H}$ Hoel. Workplace bullying as a gendered phenomenon. Journal of Managerial Psychology, 2013; 28:235-251.

\section{Commentator details}

Name: Nutmeg Hallett

Affiliation: Manchester Metropolitan University / University of Birmingham

Correspondence address: Brooks Building, Birley Campus, 53 Bonsall Street, Manchester, M15 6GX

Email:n.hallett@mmu.ac.uk

\section{Competing interests \\ None}

